\title{
THE GENDER EQUALITY STRUGGLES IN THE NOVEL OF PEREMPU- AN BERKALUNG SORBAN AND GADIS PANTAI
}

\author{
Moh. Muzakka and Suyanto \\ Universitas Diponegoro, Semarang, Indonesia \\ suyanto@live.undip.ac.id; muzakkamoh@yahoo.co.id
}

Article accepted : October - 12- 2020

Revised article: November - 15 - 2020

Approved article: November - 20 - 2020

\section{Abstract}

The struggling of gender equalities was discussed often in various disciplines and discourses, a part is in literature. This paper analyzes the gender equalities struggle in two novels: Abidah El-Khalieqy's Perempuan Berkalung Surban and Pramoedya Ananta Toer's Gadis Pantai. El-Khalieqy is a woman who has runs a pesantren "educational institute with a Moslem background" and Toer is a man who favors a nationalistic-socialist ideology, with an emphasis on literary realism. A literary -sociological and a feminist critical approach were used in analyzing both novels. The result of the analysis shows that gender struggle in the novel Perempuan Berkalung Sorban is caused by male oppression of women based on the explanation and interpretation of very patriarchal verses from the Al Qur'an (Islam religion). The gender struggle in novel Gadis Pantai is caused by male oppression of women based on feudalistic traditions, the woman as private property of men. Being placed in this feudalistic position, women then respond with struggles for equality

Keywords: gender equality, struggle, santri, feminist, feudalist

\begin{abstract}
Abstrak
Perjuangan kesetaran jender telah banyak didiskusikan dalam berbagai disiplin ilmu dan wacana, salah satunya adalah dalam karya sastra. Tulisan ini bertujuan menganalisis perjuangan kesetaraan jender dalam dua novel yaitu Perempuan Berkalung Surban yang ditulis oleh Abidah El-Khalieqy dan Gadis Pantai yang ditulis oleh Pramoedya Ananta Toer. Novel yang pertama ditulis oleh seorang perempuan lulusan pesantren dan novel yang kedua ditulis oleh seorang laki-laki berideologi realisme-sosialisme-nasionalisme. Analisis kedua novel tersebut menggunakan pendekatan sosiologi sastra dan kritik sastra feminis. Hasil analisis menunjukkan bahwa perjuangan kesetaran jender dalam novel Perempuan Berkalung Surban disebabkan oleh tindakan represif laki-laki terhadap peremuan yang berbasis penjelasan dan interpretasi ayat-ayat Al-Quran (Agama Islam) yang patriarkhis. Sementara itu, perjuangan kesetaraan jender dalam novel Gadis Pantai disebabkan oleh tindakan represif laki-laki terhadap perempuan yang berbasis tradis feodal, bahwa perempuan sebagai hak milik pribadi laki-laki. Sikap dan tindakan feodal, berkuasa, dan tidak menghargai perempuan dalam kedua novel itu oleh perempuan direspon dengan perjuangan kesetaraan jender.
\end{abstract}

Kata kunci: kesetraan jender, perjuangan, santri, feminist, feodal

\section{INTRODUCTION}

The relation between the roles of men and women which is built by various sociocultural factors is an issue that has is often overlooked in various fields of social sci- ence, such as philosophy, sociology, anthropology, and others (Sundari, 2020). In one of the earliest feminist movements in the $15^{\text {th }}$ century, Christine de Pizan wrote about the injustices experienced by women. Subsequent devel- 
opment, Mary Wollstonecraft (1759-1797) (Raddeker, 2014) was the first feminist who claimed the existence of oppression against women caused by patriarchal traditions that makes women subordinate (Collins, 2012; Farmacelia, 2010; Kapoor, 2017; Tong, 2010). Gender issues are also frequently questioned in language and literature. Within some literature writers criticize gender issues in their work, whether in novels, short stories, poetry, or other types of work. In literature, feminist literary criticism theory was born, which focuses on gender equality within literary texts. The four major points of gender-based criticism are gender differences, gender inequality, gender oppression, and structural oppression theories and its variations (Ritzer, 1996; Suyanto, 2014). The theory of gender difference is supported by cultural feminism, institutional role theory, as well as phenomenological and existential theories. The theory of gender difference attempts to describe, explain, and trace the implications of the differences in behavior and life experiences of men and women. The primary three theories of gender difference each argue that the differences between men and women are immutable.

One of the foremost gender inequality theorists is William Edward Burghardt $\mathrm{Du}$ Bois, an African American abolitionist, activist and feminist scholar. Gender inequality theory is based on four assumptions: (a) men and women in society are positioned only dif- ferently. This inequality is demonstrated by the lack of material resources, social status, power, and opportunities centered on women's actualization compared to men. (b) Inequality stems from social organizations or institutions, not from biological or personal factors; (c) there is no fundamental natural difference between men and women, but situationally, women are less powerful in actualization than men; and (d) both men and women respond to social situations and structures easily and naturally (Ritzer, 1996).

The theory of gender oppression is supported by psychoanalytic and radical feminism. According to the theory of gender oppression, the subordination of women is a result of male domination, in which men control, use, conquer, and oppress women. Domination occurs between a dominant party which succeeds in controlling another party. This pattern of oppression where women have continually been controlled, used, conquered, and oppressed by men is known as the patriarchy.

The fourth gender theory is the theory of structural oppression championed by renowned socialist and Marxian feminist theorist and the theory of intersectionality (Collins, 2012; Rollins, 1991). Socialist feminism was established through the Marxist book The Origin of the Family, Private Property and the State by Friedrich Engels. According to Marx and Engels, women's subordination is not rooted in any biological aspects, but rather from social dynamics and institutions. The basis of women's long-subordination is tied to their 
role in the family (family, Latin for 'servant'). In addition, the transitions from pre-modern systems of collecting food, hunting, craftsmen, sellers and distributors of vital goods to an agricultural- and livestockbased economic system, gave birth to the concept of property and established men as the primary beneficiaries of economic production resources. In this economic system, men (as property owners) need labor (slaves, captives, women/wives, or children) and an heir who will maintain and manage the property. Thus, the first family unit was born. (Ritzer, 1996).

In this research, we examine two novels written by two well-known novelists who are of different gender, understanding, and ideology, namely the novel Perempuan Berkalung Sorban (El-Khalieqy, 2009) and the novel Gadis Pantai (Toer, 2003). El-Khalieqy is a woman who has a background in Islamic boarding schools (santri) and is an Islamic scholar (Muzakka, 2010); while Toer is a male author who is steeped in socialist realism (Siminto, 2008; Suyanto \& Sundari, 2019). The choice of these two novels is interesting and significant in feminist literary studies because, although they are from different backgrounds and hold different ideologies, they both reveal the struggle for women face against the "wall" of patriarchy.

Although Perempuan Berkalung Sorban was published simultaneously with the emergence of Islamic novels promoted by the Forum Lingkar Pena but the substance is very different because the authors of Islamic literature generally wrote literature promoting Islamic values and teachings or make religion a setting that tends to prioritize men. In Perempuan Berkalung Sorban ElKhalieqy tries to fight for women's equality socially and institutionally (Agha, Syed, \& Mirani, 2018; Muzakka, 2010; Suyanto \& Sundari, 2019). This is noteworthy because in Muslim communities and families, women are often positioned as inferior beings by men. Muslim men legitimize their hegemony over women by "arming" themselves with several verses of the Qur'an and hadith that are understood from the textual side alone. This practice is what socio-cultural and feminist experts call gender bias (Suyanto \& Amin, 2017). By presenting a female character, the child of a kiai who lives in a pesantren community, El Khalieqy tries to question the position of women who are subjected to hegemony by men. This is of course different from the novel Gadis Pantai which has been written by a male writer who has socialist realism (Suyanto \& Sundari, 2019).

The novel Gadis Pantai, according to the author's narrative as written in the introduction to the novel written by the publisher with the title "Dari Lentera Dipantara" (Toer, 2003), is a romance that tells the story of the life of a young girl born in a fishing village in Rembang Regency, Central Java who captivates the heart of a local santri figure, a Javanese person who worked with the Dutch Colonialist. He was married to priyanyi santri (Bendoro) a con- 
cubine (istri ampilan or selir). This romance is very beautiful and enchanting. Through this novel, Pramoedya Ananta Toer has succeeded in showing the negative contradictions of Javanese feudalism practices that do not have the slightest humanistic value (Toer, 2003).

Many researchers analyze Gadis Pantai from literary and cultural point of view. One example is Siminto's “Novel Gadis Pantai Karya Pramoedya Ananta Toer: Analisis Struktural Levi-Strauss" (Siminto, 2008). Muzakka also examines this novel from a sociological perspective, especially the author's subjective view of the santri-priyayi world. In that writing, he said that Toer seemed to "scream" and sharply criticize the priyayi santri community with a cynical tone in the novel. In another part of the article, it explains that the author views the priyayi-santri world as very feudal. Although the author mentions many indicators of the shortcomings and weaknesses of the priyayisantri world, he classifies the author's views into three parts, namely (1) anti-class and gender equality, (2) authoritarian and antidemocratic, and (3) pseudo- and hypocriticreligiosity (Muzakka, 2010).

Even though many researchers have examined how the two novels draw from various literary and sociological theory, including feminist literary theory, no one has examined the novels through the lens of the struggle for gender equality, particularly within the comparative studies field. Therefore, a comparative study of how each text portrays the struggle for gender equality is a novelty within the field of Indonesian literature.

The objects of this research are the novels Perempuan Berkalung Sorban (PBS) by Abidah El-Khalieqy and Gadis Pantai (GP) by Pramoedya Ananta Toer; while the formal object is the portrayal of gender struggles within literature. The perspective of the study is based on the sociology of literature, namely the study of feminism, so this research is classified as literature research.

In this regard, the data collection in this study is through literature review, using primary and secondary data about gender struggles in $P B S$ and GP novels. Once collected, the data are analyzed through a literarysociological approach with a concentration on feminist literary criticism. This method is used to analyze data on aspects of gender inequality, especially the struggle of female characters in society who adhere to patriarchal ideas in the PBS novel and the GP novel. This is in line with Swingwood's opinion that literature is not just a side material in life, but rather a reflection of society even though they realizes that literature is created by the author using a certain set of tools (Faruk, 2012).

The emergence of gender struggles in the two novels is primarily due to the patriarchal hegemony that has repressed women. In this regard, Wirjosutedjo and Pradopo conclude that apart from the marginalization of women caused by men, is caused by power. The form of 
marginalization is (1) women as colonized people, (2) women as workers, (3) women being dominated by men, (4) women subordinated by women, (5) coercion by women, and (6) women dominated by women (Ratna, 2004).

\section{FINDING AND DISCUSSION}

As explained previously, both female and male authors work to present the struggle for gender equality in literature, as seen in the $P B S$ and GP novels. To understand how the gender struggle presents in these novels, the ideology or understanding support patriarchal systems.

\section{Gender Struggle in PBS Novel}

Throughout her life, the female character in $P B S$ is hegemonized by the patriarchal system entrenched both within her family and the boarding school. The system has cultivated an unfair division of labor between men and women and is supported by religious arguments derived from the text of the Qur'an and the hadiths that prioritize men over women. In addition, with these arguments men oppress women by restricting their rights rather than fulfilling the obligations to women. This is where women are suppressed and treated as second-class citizens within the patriarchal system.

Part one of this novel tells the life of the little Anisa character in her family environment and the pesantren where she was raised by her father (PBS, pp. 1-49). Since childhood,
Anisa has been positioned differently from her two older brothers, Rizal and Wildan, within her family. As a girl, she had to be polite and refined, had to get up early to clean the bedroom, and regularly helped her mother in the kitchen. Her father forbade her from learning to ride a horse. This is different from her two older brothers who had the freedom to play, talk and laugh out loud, could sleep again after dawn prayers, and could even wake up a little later. When Anisa was caught learning to ride a horse with her relative Lek Khudhori, her father scolded her, and she was even restricted from leaving the house except going to school and to the Islamic boarding school.
"You're being smart, Nisa. Is that what your father and mother taught so far. You are a girl. Do you want to be a he- ro? Pencilakan, Pethakilan! You know whose child you are, huh!"
“... Now listen! From today on, you must not go outside the house other than to school and to the cottage. If you are caught once disobedient, Father will lock you in your room for a week. Got it!" (PBS, pp 33- $34)$.

Another form of bias Anisa faces is that her father and mother constantly reinforce the distinct duties and obligations of women in the household. Although Anisa has not reached puberty (baligh), Anisa's parents require her to wear a headscarf while her siblings are still allowed to wear shorts and freely frolic outdoors. The books Uqudullujain, Risalatul Mahidz, Akhlaqun Nisa', Mar'atus Sholihat, and Akhlaqul Banat teach related to the duties and obligations of women. Many of these books discuss a variety of issues regarding women like 
menstruation, marital relationships, a wife's obligations to her husband, the characteristics of a pious wife, and so on. The books are filled with gender bias which positions men higher than women. All these books were taught to female students by Ustadz Ali and are conveyed from a male perspective to that they reinforce the gender hierarchy, as demonstrated in the following excerpt from the second part of $P B S$.

It is stated in the book that the woman is indeed human, but her intellect and religion are imperfect. It is evident that men's intellect exceeds that of women, said Ustadz Ali who became the bad guy.... Then men became scholars and priests both high and small, and when writing, men's writing was more scientific than women's writing. Men also became great and great leaders such as Imam Hanafi, Imam Maliki, Imam Hambali, Imam Shafi'i, and Imam Ghozali.... (PBS, p.71).

If part two of $P B S$ tells more about Anisa's character and childhood, detailing the patriarchal dogmas within her household and the boarding school, then the third part of this novel further exemplifies the power men hold over women, namely through matchmaking and marriage. In this section, Anisa is still studying at Madrasah Tsanawiyah, but her parents decide she will marry Samsudin, the son of a well-known kiai in his city.

Her marriage with Samsuddin is not based on love. Samsuddin has sex with her against her willing. Anisa began to dare to resist against Samsuddin although it is contrary to the teachings of Islam. Samsudin even cheats on Anisa and play around with other women.

With her intelligence, she was not defeated when faced Samsudin's oppression. Anisa agreed to let Samsudin marry the widow. In fact, she did not mind allowing the other woman named Kulsum to live in the same house with them. With the presence of Kulsum and her child in the Samsudin family, Anisa is even more enthusiastic about studying and continuing her studies even though Samsudin refuses to pay her school fees. With an enthusiasm inspired by encouragement and letters from Lek Khudhori, who was studying in Cairo, Anisa attended school and studied various sciences, because according to her, women who were smart, intelligent, and skilled would be able to gain equality with men.

The struggle of women from Islamic boarding schools to win achieve gender equality has been led by agile, intelligent women like Anisa. El Khalieqy's character often questions her parents about why women are considered inferior to men. She always questioned why women are relegated to household tasks of managing the kitchen and family, while unable to become government employees. Why should women appear gentle and polite, and avoided riding horse, cars an fighting? Why are women not allowed to study to at high levels and become leaders of the ummah (people) or government officials.

Anisa did not get satisfactory answers from her parents, ustadz, or teachers at school, but she always received satisfying answers and so- 
lutions from Lek Khudhori. Because of her conversations with Lek Khudhorilah, Anisa who initially wanted to be good at riding horses like Putri Budur or Ratu Balqis, became very enthusiastic about studying. She wants to be the kembang peradaban 'interest of civilization' just as Lek Khudhori hoped for. Secretly, she continued to practice riding horses with the help of Lek Khudhori. She did this small act of rebellion solely because she wanted to show that women were capable of riding horses like men. Even so, she has also memorized the Koran 30 juz, studied nahwu and sharaf, as well as several books taught in the pesantren.

Even though Lek Khudhori was in Cairo, she continued to recite the Koran with Ustadz Ali. However, every time Ustadz Ali explained expectations related to a wife's obligation to her husband or offered bias opinions, she would ask critical questions. For example, when Ustadz Ali explained that a hadith contained a passage about a woman whose husband invited her to have intercourse, who then delayed until her husband fell asleep, she would be cursed by Allah. Because the ustadz did not mention the wife's rights when explaining the hadiths, Anisa questioned the opposite, namely is a man who cheats or commits adultery with a prostitute punished? And what are the rules for a man who is invited to have intercourse with his wife, but procrastinates until his wife falls asleep? Anisa's questions often make the ustadz flustered. Many other questions raised by this figure to Ustadz Ali and his mother around the hadiths which she thought were unfair ( $P B S$, pp.71-93).

Although Anisa has no power to refuse her parents' decision for her to marry her father's son's friend, the peak of Anisa's struggle to fight patriarchal systems is her enmity with Samsudin, her husband. Moreover, when Samsudin regards her just as an object to satisfy his lust and does not treat her properly according to shar'i (Islamic law), Anisa was consistantly opposed to the arguments and procedures on how to have intercourse with her husband.

"Well! Well! Listen Samsudin! First, what I want to say is that you are a sick man. Your illness has led you to marry me. But marriage cannot be based on one disease. That's why I want to convict you. Do you hear now?"

He was silent with his eyes bulging and teeth chattering as if he had epilepsy. I did not care and continued my words with what is. ( $P B S, \mathrm{p} .114)$

Because of her household disharmony with Samsudin, Anisa is even more eager to study and finish her school at Madrasah Aliyah, especially with the support and advice of Lek Khudhori through his letters. He sends her beautiful poetry and passages, which are occasionally accompanied by tapes of Egyptian singers and photos of Lek Khudhori himself. Anisa is excited to learn, read, and study, because of these letters and his encouragement. Anisa begins to fall in love with Lek Khudhori, she also catches Lek Khudhori's sincere and subtle expressions of love.

Even though Samsudin married a widow 
named Kalsum whom he had impregnated and may also have had other affairs, Anisa was never broken. In the end, he learned his lesson when Anisa refused Samsudin's request to spend more time with him, because he was jealous of Lek Khudhori. And when Lek Khudhori returned from Egypt, Anisa returned to her parents' house to visit hin, Samsudin was increasingly angry with Anisa. He not only cursed Anisa, but also beat and hurt her. Finally, Anisa divorced him.

After her divorce from Samsudin, Anisa was freed from the shackles of men who made her subordinate. However, because the family relationship between Anisa and Lek Khudhori was close enough, to avoid slander related to Anisa's status as a widow, Lek Khudhori was asked for her understanding not to live in the pesantren and Anisa's father's house. Lek Khudhori finally left the pesantren.

Love had grown between Anisa and Lek Khudhori especially when Anisa was hurt by Samsudin. Anisa's parents have not been able to agree to their relationship. Anisa chose to move to Yogyakarta to continue her education after graduating from Madrasah Aliyah.

Because it was already outlined by God that Anisa should be matched with Lek Khudori, even in Yogyakarta she met people she respected and loved. Finally, with the blessing of her parents, Anisa married Lek Khudhori who also happened to be a lecturer at a university in Yogyakarta.
However, at the end of the story, Anisa still has to fight for her own life because her beloved husband, who has given her a child, has to leave her forever. Even though she was grieving, she still powered on and struggled to achieve this goal, namely, to raise the image of women and fight for gender equality. Even though she has to fight on her own, while raising her only child, Anisa wants to continue to prove to Lek Khudhori, her husband, that one day she will be able to become the "flower of civilization."

\section{Gender Struggle in GP}

The main figure in Gadis Pantai is the daughter of a fisherman from a fisherman village, who is married to a high-level priyayi named Bendoro, the Regent of Karesidenan Jepara Rembang. The characters have different and very contrasting backgrounds, as Gadis Pantai (beach girl' in English) is a fisherman's child and is considered a commoner, poor, ignorant around religion, and uneducated; while Bendoro is a priyayi, a wealthy regional ruler, who is highly educated, knowledgably about the Koran, and has made the pilgrimage twice. Because of their backgrounds, Gadis Pantai is subordinate to Bendoro. Additionally, before marrying Gadis Pantai, Bendoro also married other women. However, his previous marriages were temporary, as after his wives gave birth to a child, he divorced them. Bendoro takes care of the children, but the mothers were not allowed to visit them.

Literature is a tool to fight for certain ideologies, that is, an ideology that the author understands and believes in. The emergence of conflicts in literature is a battle between the 
dominant ideology or the ruling ideology and the ideology that the author is fighting for. The ideology that is being fought for emerges due to awareness and/or a clash of ideological viewpoints in the face of the dominant or ruling ideology (Faruk, 1994; Muzakka, 1998). In GP Pramoedya Ananta Toer tries to fight for a hegemonic ideology, namely the ideology of socialist realism which demands an equality of position to fight against feudalist ideology, which reaffirms hierarchical structures. One of the most prominent ideological battles in GP is the struggle of women against the hegemony of the feudal patriarchy.

As illustrated a little above, GP takes two characters with contrasting characters who come from two different places and social backgrounds and uses them to illustrate the problem of class inequality. Gadis Pantai is the daughter of a fisherman who is educated by her parents and community in a fishing village. She cannot read, write, and doesn't understand religion because in this poor fishing village, there are no social facilities such as schools or mosques. She only knows things related to life as a fisherman. However, behind her poverty and ignorance, thanks to the upbringing of her family and society, she has a strong basic character, of high honesty, compassion for others, and egalitarianism.

On the other hand, Bendoro is from a city, born into a rich and priyayi family. Since childhood he received a Dutch education so that he grew up educated and fluent in Dutch. Because of this, he had an important position in the Dutch East Indies colonial government, and was a regent as well as being a regional ruler in the Jepara Rembang Residency. Besides receiving a Dutch education, he also received religious education. He is diligent in praying, securing, and reciting the Koran in his daily life. He also likes to give alms and helps beggars regularly around his residence. He had made the pilgrimage twice, thus, he was not only a great priyayi, but also a devout santri.

Even though he is a powerful santri priyayi, Bendoro still acts like any other ruler, namely as a "king" who must be respected no matter what, including in his marriage. A great priyayi must also have an equal and respectable "empress" - not a lowly commoner as a wife. However, because he is unable to find a "worthy" wife, he only wants a beautiful woman close by such as a woman like Gadis Pantai.

The author clearly describes this social inequality from the beginning to the end of the novel. In the early part of this novel, it is noted that the wedding procession between Bendoro and the Gadis Pantai is not like a normal marriage. Initially Bendoro went with an envoy to Gadis Pantai's parents home to request the marriage. A few days later several messengers came with jewelry, clothes, money, etc. for the wedding procession. At the wedding Bendoro was not present but his presence was represented by a keris brought by a messenger

After the wedding procession, Gadis Pantai was brought to Bendoro's house, escorted by her parents, siblings, uncles, and the head of her village. Once she arrived, the differences in their social class became even more apparent. Just as with royalty, the group that escorted her did not immediately meet Bendoro, but had to wait for Bendoro who was sleeping. They were served only by celibates. After the her parents and siblings were placed in separate rooms, the beach girl was introduced to 
the rules of the Bendoro house by a woman who always accompanied him.

Throughout the story, the author's differences in social class are clearly expressed in the unbalanced household life in the "kraton" setting of a Bendoro Regent. Even though Bendoro treats Gadis Pantai affectionately, she is still treated as a servant who must comply with Bendoro's wishes. Even though she is Bendoro's wife who holds the title of main woman ( mas nganten ), she does not have the slightest power over her household. She must always serve Bendoro.

From the differences in social class in the novel, the power dynamics between the priyayi-santri and the common class are very stark. Priyayi-santri are superior, dominant, and hegemonic; while fishermen are a class of commoners who are inferior, marginal, and superordinate to the priyayi-santri. This dynamic automatically places Gadis Pantai in an inferior position within the Bendoro family. She becomes an "object" controlled and owned by Bendoro. Seeing the very sharp social inequality confirms the existence of gender bias or gender inequality in the Gadis Pantai household. This is because Gadis Pantai, as a temporary wife, does not have any ability to challenge Bendoro's patriarchal hegemony. Not only around material goods, such as houses, jewelry, and other possessions, but also around other issues such as affection, attention, sexual needs, and other personal needs. She has no power to take or ask anything from her husband, and is forced to simply wait for Bendoro's love.

The gender imbalance becomes clearer at the end of the story when Gadis Pantai gives birth to a daughter. Bendoro divorces her and sends her to her parents' home without any reason. In fact, when the Gadis Pantai faced Bendoro to take care of her child, she was still thrown out of the Bendoro house. The peak of gender bias is seen in the quotation below.

"You leave this house! Bring all the jewelry and clothes. All that I have given you. I gave your father a loss, enough to buy two boats at once with the equipment. You yourself, this..., "Bendoro held out the heavy bag containing currency... severance pay. "Look for a good husband, and forget all about this building. Forget me, get it?" "Damn, Bendoro."

"And remember. Use the severance pay carefully. And ... you may never set foot in this city. Damn you if you break it. Did you hear?" (GP, pp.257-258).

From the above quotation it is quite clear that the priyayi-santri hold hegemony over the common people, as well as the patriarchal hegemony over women. At the end of the story, though the Gadis Pantai left all gifts given by the Bendoro but she was treated like a thief. She was then expelled from Bendoro's house. Thus, through the character Bendoro, Pramoedya views that the priyayi-santri world is a feudalistic world against the equality of social class and gender.

\section{CONCLUSION}

From the above discussion it can be concluded that women's struggle in seizing patriarchal hegemony does not only appear in the real world, but is also strongly reflected in Indonesian literature. This struggle is not only depicted by female writers, but also by male writers. This struggle that many women face 
Poetika : Jurnal Ilmu Sastra

Vol. 8 No. 2, December 2020
DOI 10.22146/poetika.60528

ISSN 2338-5383 (print) ; 2503-4642 (online) was depicted by a female santri who had lived in a pesantren for a long time and was very familiar with the ins and outs of Islamic boarding schools and religions. This is evident in the $P B S$ novel written by Abidah ElKhalieqie. This is different from Pramoedya Ananta Toer who depicted a woman's struggle within the santrifeudal patriarchy. If Abidah questioned the interpretation of Quranic verses and hadith, Pramoedya was against the feudalistic system where the priyayi degrade the position of women. Both stories, written by authors coming from different gender and social backgrounds show the same arguments that the position of women is oppressed under different social system. They are always treated as outsiders and expulsed from their family. Women struggle is described difficult to reach their objectives because the social system is too strong to be defeated.

\section{ACKNOWLEDGEMENT}

Thanks to Universitas Diponegoro Research and Community Service Institute that supported research team in conducting this research through a fundamental research scheme, Contract Number: 181-31/UN7.5.1/ PG/2016

\section{REFERENCES}

Agha, N., Syed, G. K., \& Mirani, D. A. (2018). Exploring The Representation of Gender and Identity: Patriarchal and Citizenship Perspectives from The Primary Level Sindhi Textbooks in Pakistan. Women's Studies International Forum, 66
(November 2017), 17-24. https:// doi.org/10.1016/j.wsif.2017.11.009

Collins, P. (2012). Social Inequality, Power, and Politica: Intersectionality and American Pragmatism in Dialogue. 26(2), 442-457.

El-Khalieqy, A. (2009). Perempuan Berkalung Sorban (3rd ed). Yogyakarta: Arti Bumi Intaran.

Farmacelia, E. (2010). The Struggle of the Other: Maggie Tulliver in George Eliot'S the Mill on the Floss. Kajian Sastra, 34(1), 6981.

Faruk. (1994). Pengantar Sosiologi Sastra. Yogyakarta: Pustaka pelajar.

Faruk. (2012). Metode Penelitian Sastra: Sebuah Penjelasan Awal. Yogyakarta: Pustaka Pelajar.

Kapoor, P. (2017). Between fact and fiction: Can There Be a Postcolonial Feminist Ethnography? Women's Studies International Forum, 60, 58-68. https://doi.org/10.1016/ j.wsif.2016.11.004

Muzakka, M. (1998). Kuli Kontrak Karya Muchtar Lubis: Sebuah Analisis Hegemoni. Kajian Sastra, 25(22), 58-64.

Muzakka, M. (2010). Perjuangan Perempuan Melawan Hegemoni Patriarkhi: Kajian terhadap Novel Perempuan Berkalung Sorban Karya Abidah El-Khalieqy. Kajian Sastra, 34(2), 128-138.

Raddeker, H. B. (2014). Feminism and Spirituality in Fantastic Fiction: Contemporary Women Writers in Australia. Women's Studies International Forum, 44(1), 154$163 . \quad$ https://doi.org/10.1016/ j.wsif.2013.12.009

Ratna, N. K. (2004). Teori, Metode, dan Teknik Penelitian Sastra. Yogyakarta: Pustaka Pelajar.

Ritzer, G. (1996). Modern Sociological Theory. Singapore: McGraw-Hill.

Rollins, J. (1991). Black Feminist Thought: Knowledge, Consciousness, and the Politics of Empowerment. Patricia Hill Collins . American Journal of Sociology, 97. https://doi.org/10.1086/229850

Siminto. (2008). Novel "Gadis Pantai" Karya Pramoedya Ananta Toer: Analisis Struktural Levi-strauss. Jurnal Studi Agama Dan Masyarakat, 2(1), 33-55.

Suyanto \& Sundari,W. (2020). Representasi Perempuan dalam Bahasa Indonesia: Studi 
Karakteristik Linguistik dalam Novel Indonesia Tahun 2000-an. Semarang.

Suyanto. (2014). Pola Karier Dosen Perempuan Perguruan Tinggi Negeri di Kota Semarang. [Ph.D. Thesis, Yogyakarta: Universitas Gadjah Mada]..

Suyanto, S., \& Amin, M. F. (2017). Representasi Relasi Jender dalam Pemakaian Diksi pada Novel "Perempuan Berkalung Sorban" Karya Abidah El Khalieki. Nusa: Jurnal Ilmu Bahasa Dan Sastra, 12(1), 55. https://doi.org/10.14710/ nusa.12.1.55-65

Suyanto, S., \& Sundari, W. (2019). The Linguistics Characteristics on the Gender Relations on Novel Gadis Pantai. 9-12. https://doi.org/10.4108/eai.13-82019.2290170

Toer, P. A. (2003). Gadis Pantai. Jakarta: Lentera Dipantara.

Tong, R. P. (2010). Feminist Thought: Pengantar Komprehensif. Yogyakarta: Jalasutra. 